\title{
Potash deposits in Africa
}

\author{
Introduction, Potash Deposits of the Republic of Congo, and Other African Potash Deposits \\ and Occurrences
}

Andrew Pedley

Elemental Minerals Limited.E-mail: pedley.andrew@gmail.com

Potash Deposits of East Africa

\section{Jana Neubert and Sebastiaan van der Klauw \\ ERCOSPLAN Ingenieurgesellschaft Geotechnik and Bergbau mbH.}

DOI: 10.18814/epiiugs/2016/v39i2/95787

There are currently no operating potash mines in Africa but exploration for potash resumed after 2005 in response to an increase in the value of the commodity and the presence of a small number of high quality deposits. There are several exploration and advanced stage projects, in the Danakil Depression of Eritrea and Ethiopia and within the coastal Congo Basin of the Republic of Congo (Fig. 1). In both regions, potash layers are hosted by evaporite sequences which formed within syn-rift or post-rift basins respectively. Resources identified in these districts are provided in Table 1. Less significant potash occurrences are hosted by the Late Triassic aged evaporites of the Khemissat Basin of Morocco, and within brines contained in near-surface sediments of playa deposits of the 'Chotts' of Libya, Tunisia and Algeria, and the Sua Pan of Botswana.

Note: In the following text evaporite rock types are distinguished from minerals by the use of a capital letter to denote rock types and italic font for minerals.

\section{Introduction to the Potash Deposits of the Republic of Congo}

The onshore portion of the Congo Basin occupies a 150 kilometre long northwest-southeast oriented coastal strip within the Republic of Congo, from Gabon in the north, to Cabinda (Angola) in the south and the deposits in this area are best accessed from the regional capital of Pointe Noire (Fig. 2).

Potash was first identified in oil exploration wells in neighbouring Gabon in 1948. The Gabonese portion of the basin was found to be significantly affected by salt tectonics and exploration efforts shifted to the Congo (de Ruiter, 1979). Based on exploration by the French Company Mines de Potasse d' Alsace S.A (MDPA), between 1959 and the late 1960s, a mine, known as the Saint Paul minewas developed at Holle (Fig. 2). The mine operated from 1969 to 1977 mining Sylvinite ${ }^{1}$ ore, with peak production of approximately 450,000 tonnes of Muriate of Potash ${ }^{2}$ per year (MDPA, 1982).

Between 1997 and 2004 Mag Industries Corporation (Mag Industries) investigated the production of magnesium from Carnallitite $^{3}$ seams in the Mengo Area, 20 kilometres northeast of Pointe Noire (Fig. 2). In 2005 it was shown that potash production from the same seams would be more profitable than magnesium production and the project configuration was changed (Rauche and van der Klauw, 2013). Evergreen Industries Holding Group became the controlling shareholder of Mag Industries and completed a Feasibilty Study, based on the solution mining of four potash 'horizons'. Construction of the mine and infrastructure began in 2014, with planned full scale production of 1.2 million tonnes per annum (Mtpa) of MoP.

Between 2009 and 2014 Australian listed Elemental Minerals Limited (Elemental), defined large potash resources at their Kola and Dougou deposits, following a large exploration campaign. In 2012 Elemental completed a Pre-Feasibility study for the Kola Deposit as a conventional underground Sylvinite mine and in 2014 this was revised to incorporate phasing of the mine development, initially 1 Mtpa production of MoP, increasing to 2 Mtpa MoP (Elemental, 2014). A Scoping Study was completed in early 2015 for solution mining of Carnallitite at the Dougou deposit.

\section{Geological Setting}

The Republic of Congo potash deposits are hosted by the Congo (sedimentary) Basin, which is the central portion of a larger basin referred to as the Aptian salt basin of equatorial West Africa, containing the Gabon basin to the north and Cuanza basin of Angola (Fig. 3) to the south. The basins occupy a 20 to $80 \mathrm{~km}$ wide part of the present day onshore and extend 100 to 300 kilometres offshore. The Congo

\footnotetext{
${ }^{1}$ Sylvinite: a rock type comprised predominantly of sylvite $(\mathrm{KCl})$ and halite $(\mathrm{NaCl})$.

${ }^{2}$ Muriate of Potash (MoP): most common saleable product of potash, comprised of a minimum of 95 weight-percent $\mathrm{KCl}$.

${ }^{3}$ Carnallitite: rock comprised predominantly of the primary potash mineral carnallite $\left(\mathrm{KMgCl}_{3} \cdot 6 \mathrm{H}_{2} \mathrm{O}\right)$ and halite $(\mathrm{NaCl})$.
} 


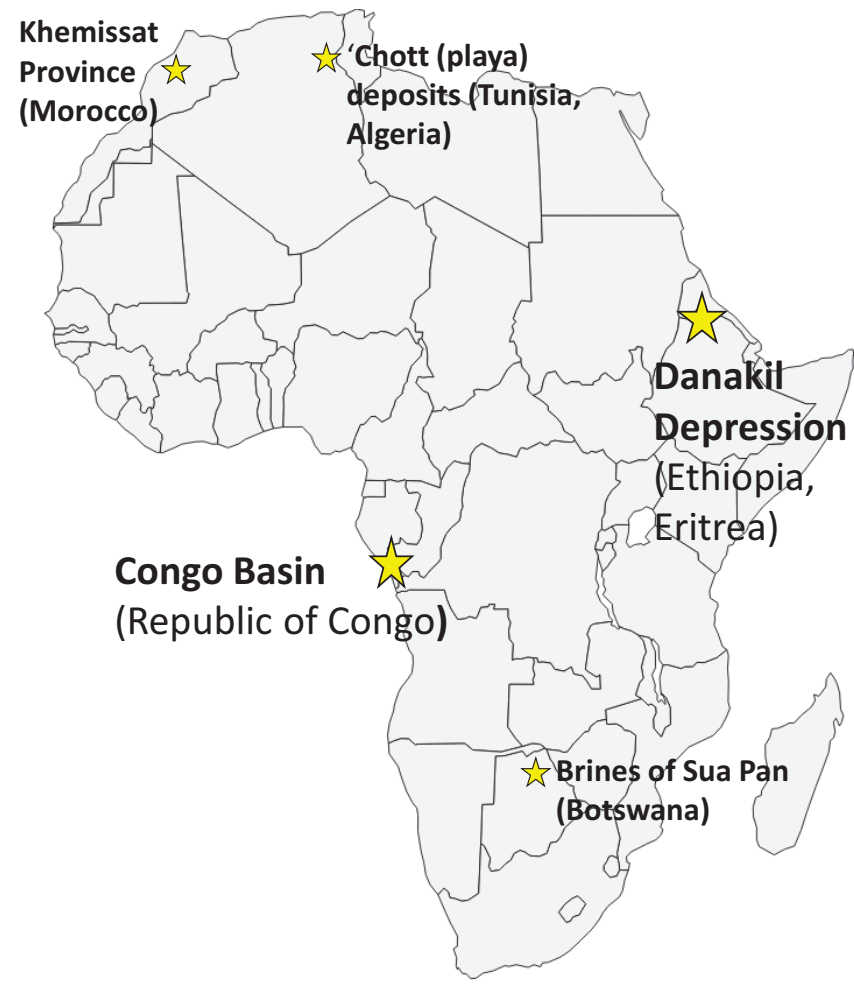

Figure 1. The significant Potash deposits and occurrences of Africa. basin is filled by a thick sequence of Lower Cretaceous to Miocene continental and marine clastic and evaporite sediments, recording the geological history of the break-up of Gondwana and the drift of the African and South American continents. The setting, timing and stratigraphy exhibit close similarities to that of the Sergipe-Algoas sedimentary basin of coastal Brazil, where potash has been mined for decades.

\section{Stratigraphy}

Before continental drift, an important transitional interval of Aptian age $(112-125 \mathrm{Ma} \pm 1 \mathrm{Ma})$ is recognised. The base of this sequence is marked by a transgressive clastic sequence grading upward from fluvial sandstones and lagoonal shales (Teisserenc and Villemin, 1989), locally known as the Chela formation (de Ruiter, 1979). It grades upwards into salt of the Loeme Evaporite Formation, deposited during middle to late Aptian times (Sérranne and Anka, 2005), which is dominated by Rock-salt ${ }^{4}$ and potash and topped by a layer of anhydrite ${ }^{5}$. The evaporites were deposited within a large steadily and relatively evenly subsiding sub-sea-level basin, fed by seepage inflow from the newly forming proto-Atlantic. The potash-entraining Ibura (salt) Member of the Muribeca Formation in the Sergipe-Algoas basin of Brazil was also deposited at this time. The evaporites are overlain by a 'Cover Sequence' of mostly littoral formations, consisting of a dolomitic basal part and a deeply weathered sand and silt rich upper part (Fig. 4 and 5). In the present day onshore there is a surface cover

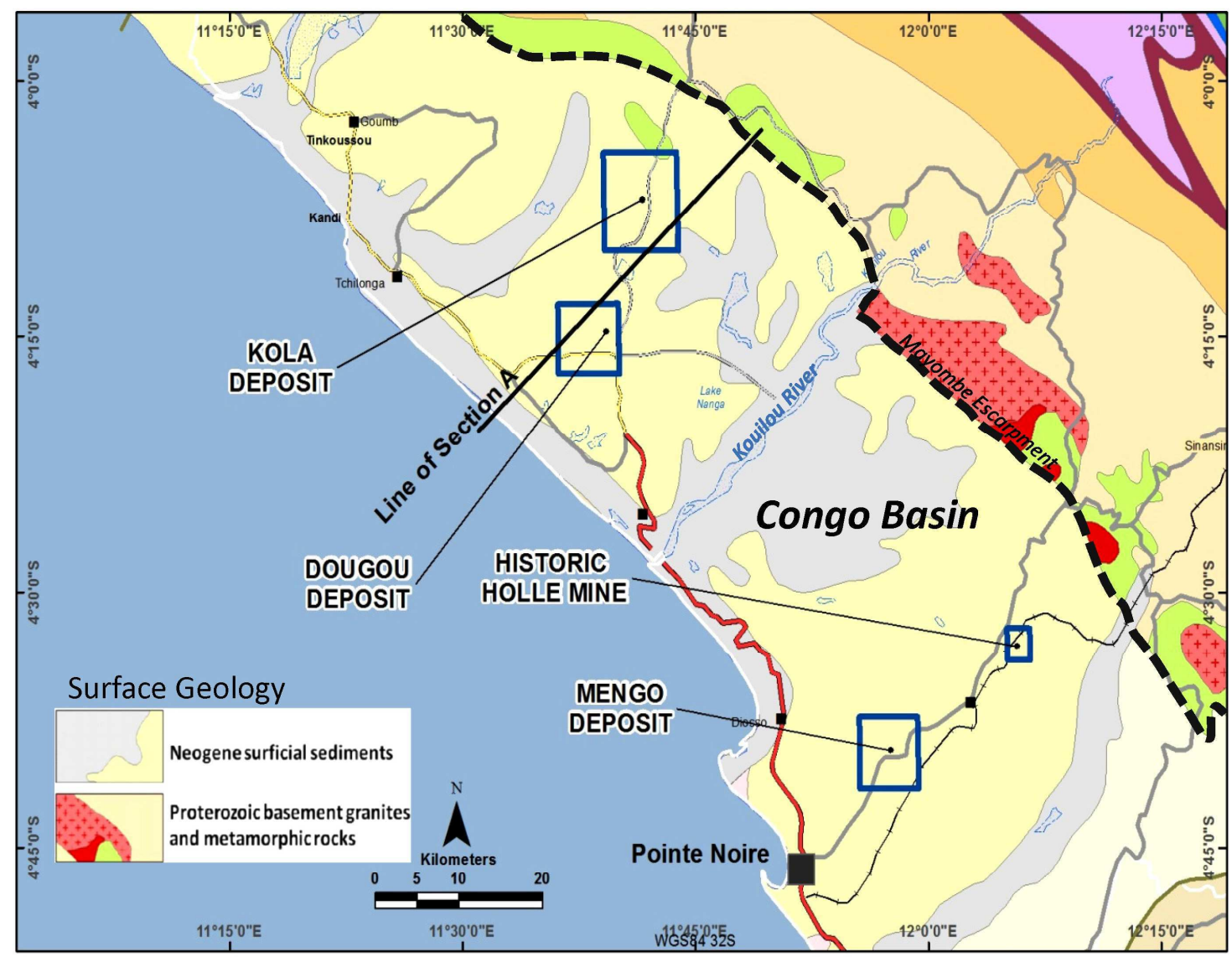

Figure 2. Location of the important potash deposits within the Congo Basin of the Republic of Congo.

\footnotetext{
${ }^{4}$ Rock-salt is a rock comprised predominantly of the mineral halite $(\mathrm{NaCl})$.

${ }^{5}$ anhydrite: calcium sulphate, $\mathrm{CaSO}_{4}$ typically formed by the dehydration of gypsum.
} 
Table 1. (JORC/NI 43-101) Resources and Reserves of African potash projects. Estimates for the less well defined occurrences/deposits of North Africa and of the Sua Pan of Botswana are given in the main text.

\begin{tabular}{|c|c|c|c|c|c|c|c|c|}
\hline \multirow[b]{2}{*}{ COUNTRY } & \multirow[b]{2}{*}{ COMPANY } & \multirow[b]{2}{*}{ PROJECT } & \multicolumn{3}{|c|}{ RESOURCES } & \multicolumn{3}{|c|}{ RESERVES } \\
\hline & & & $\begin{array}{l}\text { RESOURCE } \\
\text { CATEGORY }\end{array}$ & $\begin{array}{l}\text { MILLION } \\
\text { TONNES }\end{array}$ & $\begin{array}{c}\text { GRADE } \\
\mathrm{KCl} \%\end{array}$ & $\begin{array}{l}\text { RESERVE } \\
\text { CATEGORY }\end{array}$ & $\begin{array}{l}\text { MILLION } \\
\text { TONNES }\end{array}$ & $\begin{array}{c}\text { GRADE } \\
\mathrm{KCl} \%\end{array}$ \\
\hline Ethiopia & Allana Potash & Dallol & $\begin{array}{l}\text { Measured } \\
\text { Indicated } \\
\text { Inferred }\end{array}$ & $\begin{array}{l}1024 \\
1422 \\
1117\end{array}$ & $\begin{array}{l}17.8 \\
18.0 \\
15.9\end{array}$ & $\begin{array}{l}\text { Proven } \\
\text { Probable }\end{array}$ & $\begin{array}{c}33 \\
60.8\end{array}$ & $\begin{array}{l}28.0 \\
28.8\end{array}$ \\
\hline Ethiopia & Circum Potash & Danakil & $\begin{array}{l}\text { Measured } \\
\text { Indicated } \\
\text { Inferred }\end{array}$ & $\begin{array}{l}1230 \\
1604 \\
2099\end{array}$ & $\begin{array}{l}18.8 \\
18.3 \\
17.5\end{array}$ & $\begin{array}{l}\text { Proven } \\
\text { Probable }\end{array}$ & - & $\begin{array}{l}- \\
-\end{array}$ \\
\hline Eritrea & South Boulder & Colluli & $\begin{array}{l}\text { Measured } \\
\text { Indicated } \\
\text { Inferred }\end{array}$ & $\begin{array}{l}262 \\
674 \\
144 \\
\end{array}$ & $\begin{array}{l}17.9 \\
18.0 \\
18.0\end{array}$ & $\begin{array}{l}\text { Proven } \\
\text { Probable }\end{array}$ & - & - \\
\hline $\begin{array}{l}\text { Republic of } \\
\text { Congo }\end{array}$ & Mag Industries & Mengo & $\begin{array}{l}\text { Measured } \\
\text { Indicated } \\
\text { Inferred }\end{array}$ & $\begin{array}{l}628 * \\
160 * \\
1305\end{array}$ & $\begin{array}{l}17.4 \\
17.6 \\
17.3\end{array}$ & $\begin{array}{l}\text { Proven } \\
\text { Probable }\end{array}$ & $\begin{array}{l}148 \\
44.9\end{array}$ & $\begin{array}{l}17.4 \\
17.6\end{array}$ \\
\hline $\begin{array}{l}\text { Republic of } \\
\text { Congo }\end{array}$ & $\begin{array}{l}\text { Elemental } \\
\text { Minerals }\end{array}$ & $\begin{array}{l}\text { Kola } \\
\text { Indicated } \\
\text { Inferred }\end{array}$ & Measured & $\begin{array}{l}264 \\
309 \\
475\end{array}$ & $\begin{array}{l}33.7 \\
32.6 \\
32.3\end{array}$ & $\begin{array}{l}\text { Proven } \\
\text { Probable }\end{array}$ & $\begin{array}{l}87.9 \\
63.8\end{array}$ & $\begin{array}{l}31.7 \\
31.7\end{array}$ \\
\hline $\begin{array}{l}\text { Republic of } \\
\text { Congo }\end{array}$ & $\begin{array}{l}\text { Elemental } \\
\text { Minerals }\end{array}$ & $\begin{array}{l}\text { Dougou } \\
\text { Indicated } \\
\text { Inferred }\end{array}$ & Measured & $\begin{array}{c}148 \\
920 \\
1988\end{array}$ & $\begin{array}{l}20.1 \\
20.7 \\
20.8\end{array}$ & $\begin{array}{l}\text { Proven } \\
\text { Probable }\end{array}$ & - & - \\
\hline
\end{tabular}

Note: Reserves are not in addition to resources; they replace Measured and Indicated Resources by the application of mining, environmental and economic parameters. Resources for the Mengo deposit were adjusted by the author to remove the application of recovery factors.

of later Neogene-aged continental sediments (Da Costa et al., 2001) comprised of 5 to $50 \mathrm{~m}$ of unconsolidated quartz rich sands and silts.

\section{Loeme Evaporite Formation}

The Loeme Formation is comprised of a thick Salt Member overlain by a thinner Anhydrite Member and within the Congo Basin

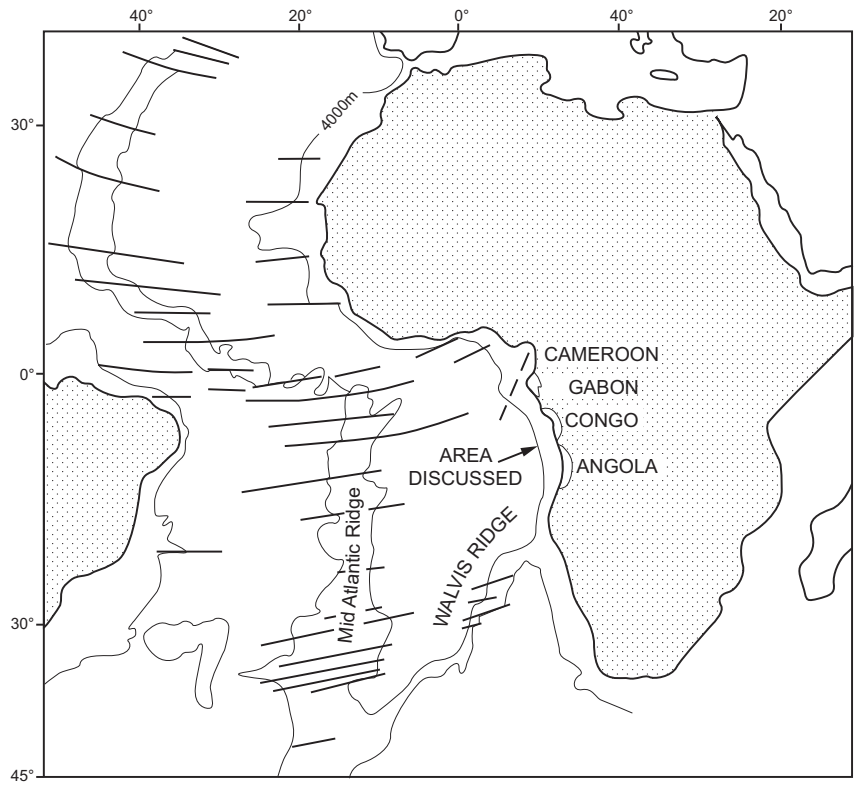

Figure 3. The Congo basin and contemporaneous Gabon and Cuanza (Angola) coastal basins. Modified from De Ruiter (1979). is at a depth of 150 to 500 metres below surface. Onshore, the Salt Member attains a maximum thickness of 950 metres in the west and thins to less than 100 metres in the east of the basin close to the Mayombe Escarpment (Fig. 4).The evaporite lithologies form welldefined sub-horizontal layers with small scale undulations and typically abrupt upper and basal contacts. The important potash seams appear to be continuous across the basin except where removed at the basal unconformity of the overlying Anhydrite Member or within rare and localized dissolution features. Where near-complete, the Salt Member is comprised of approximately 30 percent potash-bearing layers by volume, 55 percent Rock-salt, 8-10 percent Bischofitite ${ }^{6}$, with the remainder consisting of insoluble material ${ }^{7}$, anhydrite and lesser carbonates.

\section{Structural Geology}

During rifting (Berriasian to early Barremian), the upper slope was affected by extensional block faulting (Teisserenc and Villemin, 1989). Onshore, faults are mostly confined to northwest-southeast trending 'corridors' (also referred to as 'hinge zones'), separated by broad areas of little or no disturbance. Along the corridors normal faulting, half-grabens and horsts are variably interpreted. The latter give rise to the 'highs' such as Kola and Yangala (Fig. 4). On-lapping relationships evident in seismic data indicate that much of the faulting

${ }^{6}$ Bischofitite: A rock comprised predominantly of the mineral bischofite $\left(\mathrm{MgCl}_{2} \cdot 6 \mathrm{H}_{2} \mathrm{O}\right)$.

${ }^{7}$ Insoluble material (Insolubles): variably comprised of clay, silt and organic material. 


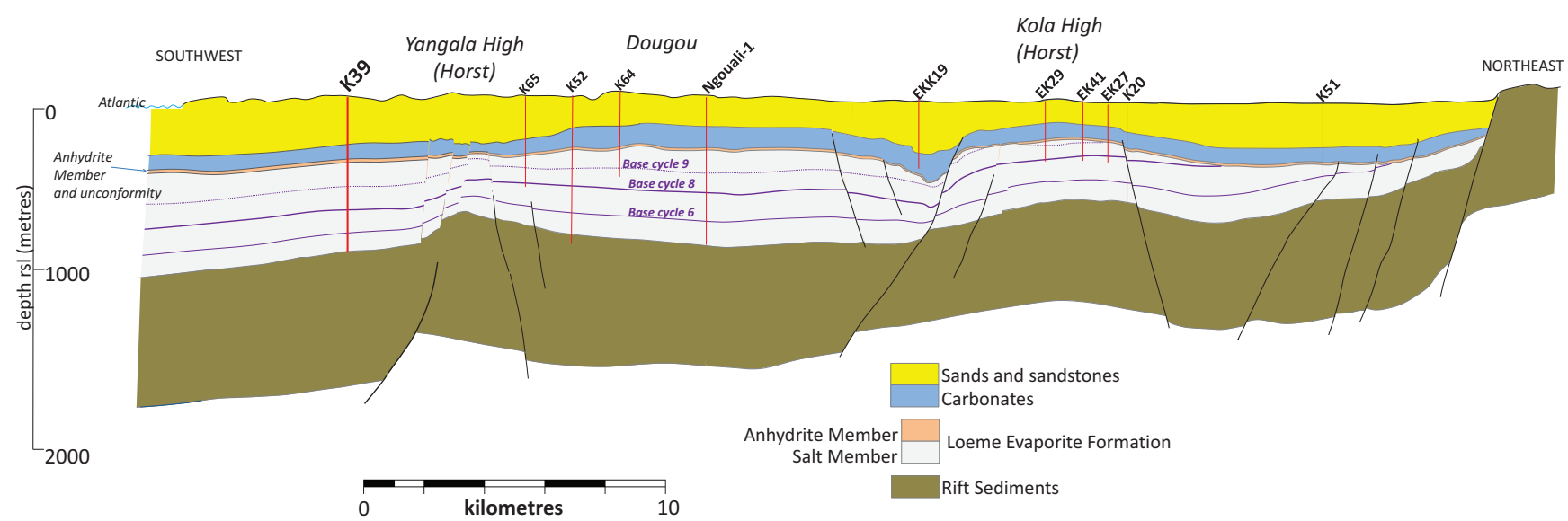

Figure 4. Cross-section through the onshore part of the Congo Basin, north of the Kouilou River as indicated by the line in Figure 2. The bases of selected evaporite cycles are shown to indicate the unconformable contact between the Salt Member and overlying Anhydrite Member. Note the significant exaggeration of the vertical scale.

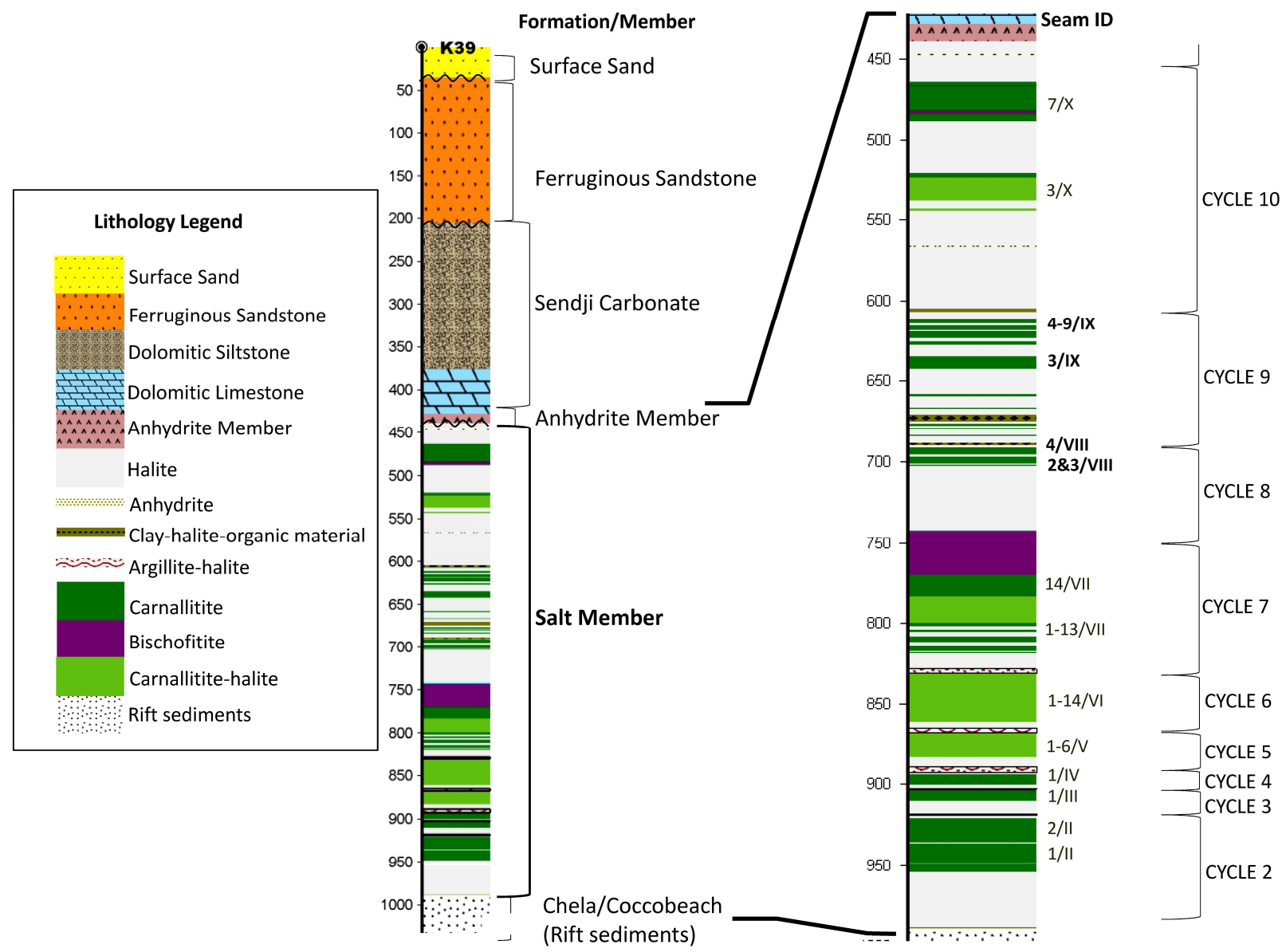

Figure 5. Geological log for historic borehole K39, showing typical stratigraphy. Evaporite cycles and potash seams are labelled.

and horst formation pre-dated the deposition of the evaporites which are less affected. Extensional structures were reactivated during the Oligocene, Miocene and Pliocene (Spathopoulos, 1996). Uplift of up to three kilometres is thought to have affected the west African margin (Sérranne and Anka, 2005). Tilting of the upper-slope may have been the main driver in dissolution of the upper parts of the Salt Member.

\section{Potash Layers}

Ten sedimentary-evaporative cycles (I to X) are recognized within the Salt Member with a vertical arrangement of mineralogy consistent with classical brine-evolution models. Potash seams are principally Carnallitite, except at certain sites where the Carnallitite has been replaced by Sylvinite, as is described below. The Carnallitite layers 

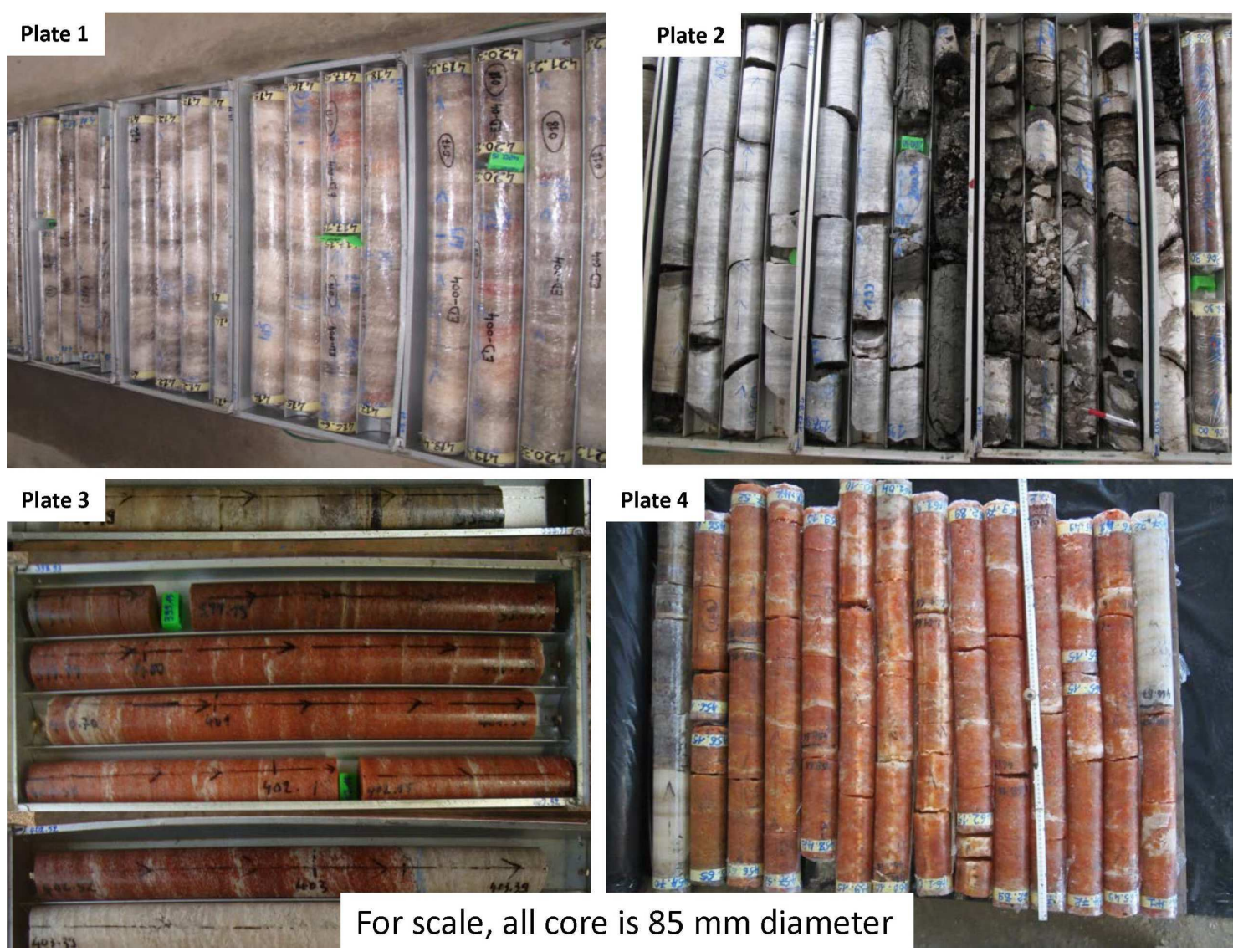

Plate 1. Massive banded Rock-salt of the Salt Member. Plate 2. Anhydrite Member with massive anhydrite upper part and more clay and organic rich lower. Plate 3. Sylvinite of seam 3/IX (Hangingwall Seam). Plate 4. Carnallitite of seam 3/IX (Hangingwall Seam) comprised of approximately 90 percent carnallite. Notice the abrupt upper and lower contacts of the potash seams.

range from less than 50 to over 90 percent carnallite by volume, are centimetre-scale to up to 12-15 metres in thickness and have largely basin-wide extent. The simple geometry and continuity of the potash layers of the Congo Basin reflects minimal disturbance of the evaporites at the time of deposition. Potash seams are named using the historic nomenclature for the area, referring to the cycle within which the seam is found then by the seam number within that cycle, sequenced from the base upwards (Fig. 5).

Although Carnallitite forms approximately 40 percent of the lower half of the Salt Member (cycles 1 to 7,) there are currently no resources defined for these layers despite some significant intervals (Compnanie Potasses du Congo, 1968). Within the upper cycles, 8 to 10, potash layers form less than 20 percent (by volume), though a small number are of significant grade and thickness. The highest grading seam of significant thickness within the basin is seam 3/IX (Fig. 5). Elemental Minerals Ltd. refer to this seam as the 'Hangingwall Seam', where Carnallitite is uniformly comprised of 89 to 91 percent carnallite, grading between 24 and 25 percent $\mathrm{KCl}$, and where replaced by Sylvinite it grades between 55 and 60 percent $\mathrm{KCl}$ and 4 to 4.5 metres thick, as at Elemental's Yangala Prospect. At the Mengo deposit, MagIndustries Corp. plan to mine four potash horizons within a 250 metre thick interval of cycles 8 to 10 , all seams being of Carnallitite.

\section{Sylvinite Formation}

Sylvinite is formed by the replacement of the precursor Carnallitite layers (D on Fig 6.), principally along the flanks (B on Fig. 6) of gentle antiformal features (A on Fig. 6) and only within the upper 50100 metres of the evaporite. Aquifers within the sediments overlying the Loeme Formation are known to contain saline connate waters (SRK Consulting, 2012). Low tensional strains associated with the antiforms may have led to the formation of micro-scale fractures in the capping Anhydrite Member, promoting the gradual seepage of this saline water (brine) into the Salt Member. The brine (rich in dissolved $\mathrm{NaCl}$ having passed through tens of metres of Rock-salt) would have moved into the Carnallitite and resulted in the dissolution of carnallite, and the formation of secondary halite (in addition to that which may already be present), leaving residual $\mathrm{KCl}$ precipitating as sylvite. This 'outsalting' process would leave a chloride brine rich in $\mathrm{Mg}$ and with small amounts of $\mathrm{K}$ and $\mathrm{Na}$, which presumably continued filtering down and laterally through the evaporite. This process was likely to have been variably 'active' over a long period of time. The replacement results in a significant loss of volume of the original Carnallitite layer; based on data from Kola, of between 50 and 60 percent, depending on the net gain/loss in halite content of the layer. The grade of the Sylvinite is directly proportional to the grade of the precursor Carnallitite.

It would appear that Sylvinite formation followed periods of (Oligocene and Miocene) uplift and tilting when dissolution of the upper part of the Salt Member and the gentle 'rolling' (and the formation of the antiforms and synforms observed at Kola and Holle) took place. On a larger scale, it follows that significant Sylvinite deposits are most likely to be located within the aforementioned structural corridors or immediately adjacent to them, associated with 


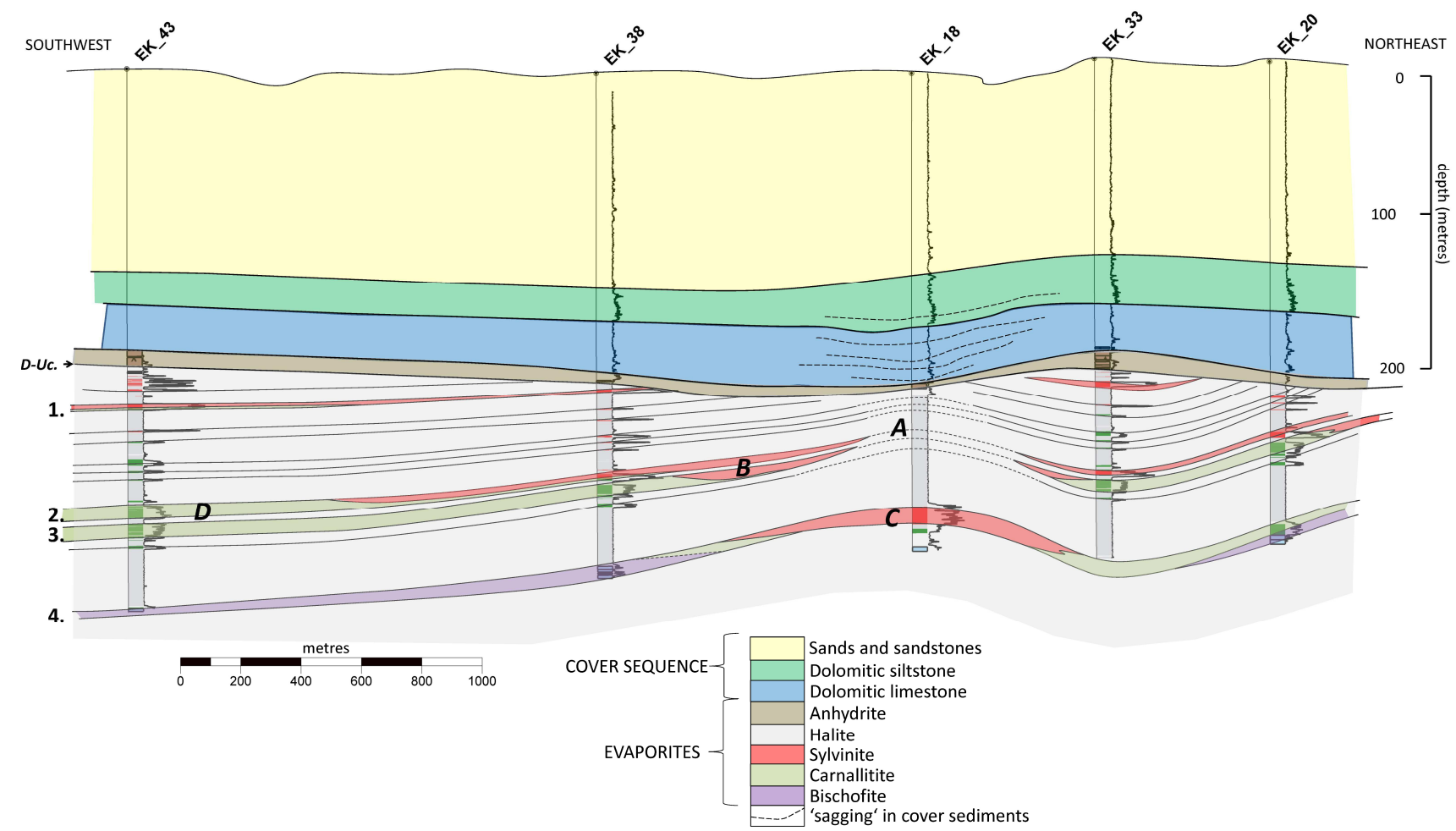

Figure 6. Cross-section through part of the Kola deposit. Note the $5 x$ vertical exaggeration. A to $D$ are referred to in the main text. Downhole gamma (API) data is shown to the right of the geology log; the relative increase in API in sylvinite vs carnallitite is evident.

gentle folding. A very similar relationship between Sylvinite and gentle antiformal features is observed in the Taquari-Vassouras potash mines of Brazil (Carvalho et al., 1995).

Localized thick 'lenses' of Sylvinite have been intersected at Kola at the top of cycle 7 (C on Fig. 6), where ordinarily only thick Bischofitite and minor Carnallitite is present. One possible mode of formation of this potash is that gravitational filtering of $\mathrm{Mg}$ and $\mathrm{K}$ rich brine (sourced from the leaching of the higher potash seams) into the Bischofitite, lead to 'outsalting' reactions, first forming carnallite and then sylvite. A similar multi-stage conversion of Bishofitite is interpreted in the East African deposits as described further in this paper.

\section{Summary of Potash Resources and Potential of the Congo Basin}

The potash resources for the Mengo, Kola and Dougou deposits are each over a billion tonnes (see Table 1) and are open laterally. These deposits compare very favourably with Sylvinite and Carnallitite deposits globally, being of excellent grade, simple mineralogy and geometry, at relatively shallow depth and having very low insoluble content. If defined, a resource for seam 3/IX (Elemental Minerals' Hangingwall Seam) would likely be the world's highest grade potash deposit at close to 60 percent $\mathrm{KCl}$. Based on historic data it is possible that the remaining Sylvinite tonnage at Holle is approximately 30 million tonnes, though this is uncertain. There may be potential to increase this resource with further drilling.

There is the potential to expand the Congolese deposits significantly, especially the Carnallitite seams which likely extend for tens of kilometres beyond their currently explored limits. It is probable that between 30 and 100 billion tonnes of Carnallitite grading over 18 percent $\mathrm{KCl}$ are present within the onshore portion of the Congo Basin at between 200 and 1,000 metres depth. Large Sylvinite deposits are more difficult to discover being controlled by a combination of structural setting and the presence of potash seams within the upper parts of the (remaining) Salt Member. Seismic data interpretation tied in with available borehole data is an essential component of such exploration.

\section{Introduction to the Potash Deposits of East Africa}

The known potash deposits of East Africa are hosted by the evaporite sediments of the Danakil Depression, adjoining the rift controlled Afar in northeastern Ethiopia and southeastern Eritrea (Fig. 7). Much of the area is more than $100 \mathrm{~m}$ below sea level and is characterized by a hot, dry climate with average temperatures ranging from $27-41^{\circ} \mathrm{C}$ throughout the year. The area has active hot springs and a high geothermal gradient, reflecting the active-rift setting.

Potash was discovered in the Dallol region in 1906 and was first exploited by an Italian company Compagnia Mineraria Coloniale (CMC). CMC mined near surface carnallite, gathered in heaps to be "naturally" leached by air humidity, resulting in its transformation to sylvite and $\mathrm{MgCl}_{2}$ brine. Between 1925 and 1929 some 25,000 tonnes of sylvite were sent by rail from Dallol, with a product that averaged $70 \% \mathrm{KCl}$ (J. Warren 2015, pers comm., 2015).

In the 1950s the American Ralph M. Parsons Company (Parsons) discovered a shallow ( $<50 \mathrm{~m}$ depth), relatively small Carnallitite deposit (Parsons, 1966) in an area characterized by high heat flow and circulation of hot brines (J. Warren 2015, pers comm., 2015). 


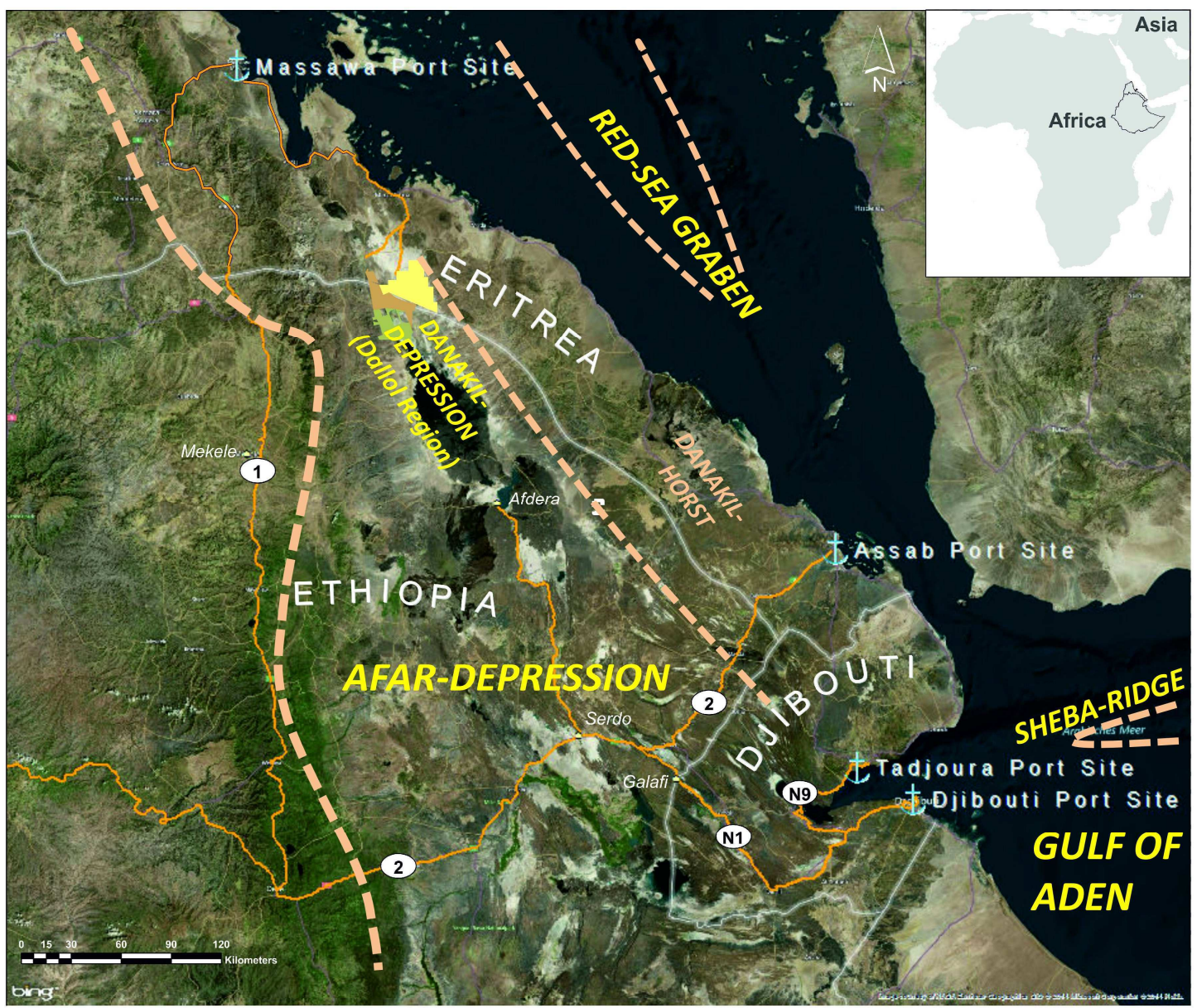

Figure 7. Satellite Image of the Danakil Depression in northeast Africa, straddling the Ethiopia/Eritrea border and showing the approximate location of selected Exploration and Mining Licenses of the companies South Boulder Mines (yellow, Eritrea), Circum Minerals (brown, Ethiopia) and Allana Potash (green, Ethiopia) in the Danakil Depression; the Ethiopian / Eritrean Boundary and Roads are schematic only.

The "Crescent" deposit was unsuited to commercial mining due to marked heat flow and the brine problems and further exploration focused on the "Musley deposit", where initial drilling had shown the existence of potash mineralisation at depths of between 50 and $200 \mathrm{~m}$. Based on over 140 drill holes at Musley, in 1965 Parsons sank three trial shafts to mine and process the Sylvinite but after only two years of trial operation an influx of water flooded the mine. After failed attempts to solve the water problem, Parsons ceased activities in 1968 .

Guided by the historical work, exploration campaigns by several companies were initiated in 2008-2009. More than $350 \mathrm{~km}$ of seismic lines, gravimetric surveys and more than 300 exploration drill holes have been completed (Beijing Sinoma, 2014; Rauche and van der Klauw, 2013; South Boulder Mines, 2014; Circum Minerals, 2014).

The location of three of the licence areas, in the north (South Boulder Mines), centre (Circum Minerals) and south (Allana Potash) are shown in Figure 7, and the publicly available details of recent estimation of mineral resources and reserves (South Boulder, 2014; Circum Minerals, 2014; Allana Potash, 2014) is presented in Table 1.

\section{Geological Setting}

The Danakil Depression of Ethiopia and Eritrea is an area of intense volcanic and hydrothermal activity (Ayele et al., 2004; Wright et al., 2006), with potash occurrences related to rift magmatism, marine flooding, and deep brine cycling during the extensional tectonic regime. It is part of the Afar Triple Junction and is located in the axial zone of the Afar rift, near the confluence of the East African, Red Sea and the Gulf of Aden rifts (Holwerda and Hutchison, 1968; Hardie, 1990).

More than $970 \mathrm{~m}$ of Rock-salt - dominated Quaternary evaporite beds are known beneath the present "Dallol" saltpan of the northern part of the Danakil Depression (Holwerda and Hutchinson, 1968; Brinckmann and Kürsten, 1971; Augustithis, 1980; Rauche and Van der Klauw, 2013; Warren in press). To the south of the salt pan, bedded Pleistocene evaporites may underlie the entire Danakil Depression. The exact age of the evaporite sequence and the potash mineralisation is uncertain, but recent observations suggest that the clay and mud with anhydrite nodules found below the evaporite sequence could be equivalent to the Zariga Formation which would indicate a mid-Pleistocene maximum age (Holwerda and Hutchinson, 1968).

\section{The Evaporite Sequence and Potash Mineralisation}

The Danakil contains 3 main potash bearing minerals; sylvite, 
carnallite and kainite $\left(4 \mathrm{KMg}\left(\mathrm{SO}_{4}\right) \mathrm{Cl} \times 11 \mathrm{H}_{2} \mathrm{O}\right)$ which can in principle, be used for the production of Muriate of Potash (MOP) and Sulphate of Potash (SOP). Further-more, the mineral kieserite $\left(\mathrm{MgSO}_{4} \times \mathrm{H}_{2} \mathrm{O}\right)$, is present in the deposit, which is favourable for SOP production. The current interpretation of the exploration results shows that the historic occurrences and recently defined deposits are part of one single evaporite sequence with local depth, thickness and mineralogical variations between the marginal and central part of the Depression. It is assumed, that these variations are mainly controlled by offset along faults related to rifting processes, as well as by the secondary transformation of the original mineralogical composition by infiltrating brines and high temperature, as described in more detail later in this text.

The stratigraphy is illustrated by the cross-section in Figure 8 and was previously described by Holwerda and Hutchinson (1968) and updated by Rauche and van der Klauw (2013). According to recent exploration activities it is comprised of 6 Members of variable thickness, described, from the base upwards, as follows:

The Kainitite Member overlays the Lower Rock-salt and is dominated by kainite with some halite and subordinate amounts of kieserite, carnallite and insoluble material. The material consists of fine-grained crystalline kainite interbedded with Rock-salt. Near the top of the member the kainite content is locally up to 90 percent. The Kainitite is characterized by its distinctive amber colour.

Above this the Intermediate Unit has recently been subdivided into an Upper Carnallitite Member and a Lower Carnallitite Member, separated by a Bischofitite Member. The Lower Carnallitite Member is dominated by carnallite and / or kieserite with appreciable amounts of halite and subordinate insoluble materials anhydrite, sylvite and kainite. Bedding is very distinct and in general has rulerstraight bedding planes between kieserite and carnallite dominated bands.

The Bischofitite Member, where present, is dominated by bischofite ( 90 percent) $\left(\mathrm{MgCl}_{2} \times 6 \mathrm{H}_{2} \mathrm{O}\right)$ with layered sections, consisting of an interlayering of halite, carnallite and kieserite. Locally these intercalations can reach a thickness of up to $1.5 \mathrm{~m}$. Bedding is very distinct in the kieserite/halite dominated sections and in general ruler-straight bedding planes occur between layers dominated by different minerals. Only locally contorted or folded bedding planes are observed, which are attributed to localised slumping.

The Upper Carnallitite Member is located below the Sylvinite Member or the Marker Beds (when the Sylvinite Member is not present) and above the Bischofitite Member and is dominated by carnallite with appreciable amounts of halite and subordinate amounts of kieserite, sylvite, anhydrite, clay and/or dolomite. The Upper Carnallitite Member is significantly thicker than the Sylvinite Member above.

The Sylvinite Member is dominated by halite with appreciable amounts of sylvite (locally up to 35 percent), and subordinate amounts of carnallite, anhydrite, clay and / or dolomite ${ }^{8}$. This unit hosts the reserves for Allana Potash's proposed solution mine.

At the top of the Houston Formation are the Marker Beds (Member) which have a distinct co-association of interbedded Rock-salt with anhydrite lamina, along with minor amounts of potash minerals. These beds then pass up gradationally into the massive Upper Rock-salt, overlying the Houston Formation.

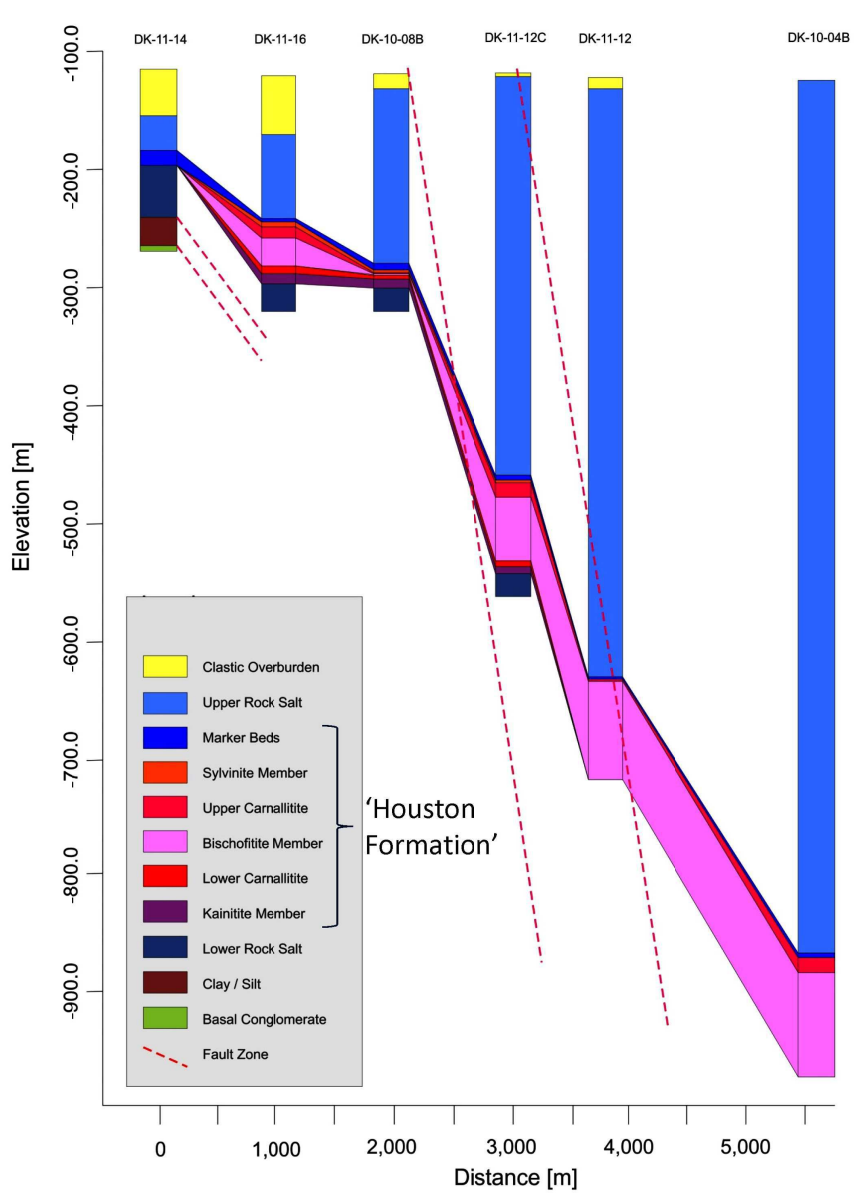

Figure 8. Simplified geological Cross Section through the Allana Potash Drill Holes DK-11-14, DK-11-16, DK-10-08B, DK-11-12C, DK-11-12 and DK-10-04B (Rauche and van der Klauw 2013). 10x vertical Exaggeration.

The thickness of the individual potash bearing members varies and is greatest in the northernmost part of the explored section of the basin. Table 2 gives an overview of the depth and thickness of the potash mineralisation as well as thicknesses of the individual potash members for the northern, central and southern parts of the basin, according to exploration results publicly available up to the end of 2014 .

\section{Secondary Alteration}

The original mineralogy may be modified by a number of reactions of the original minerals with a fluid phase (water or brine) and / or by the influence of higher temperature at deeper parts of the deposit. For example, for the Sylvinite Member a single step reaction is proposed, whereby the original composition is replaced by halite, anhydrite and $\mathrm{KCl} / \mathrm{NaCl}$ brine. For the Upper Carnallitite Member, the initial step is the transformation of the original composition to sylvite, halite, anhydrite, and possibly small amounts of polyhalite and $\mathrm{MgCl}_{2}$ brine. In a further step the transformation of this intermediate composition may occur, as for that described for the Sylvinite Member. These reactions generally significantly reduce the volume of the solid material and a brine filled porous structure remains, which is actually a residual rock mainly formed from the

\footnotetext{
${ }^{8}$ dolomite -an evaporite mineral with the chemical formula $\mathrm{CaMg}\left(\mathrm{CO}_{3}\right)_{2}$
} 
Table 2. Summary of Depth and Thickness of Potash Mineralisation for each Member for the northern (South Boulder Mining, 2014), central west (Circum Minerals, 2014) and southern (Allana Potash, Rauche and van der Klauw, 2013) part of the Danakil Potash Deposit according to Exploration Results up to the end of 2014.

\begin{tabular}{|l|c|c|c|}
\hline & NORTH & $\begin{array}{c}\text { CENTRE } \\
\text { (WEST) }\end{array}$ & SOUTH \\
\cline { 2 - 4 } & $\begin{array}{c}\text { South Boulder } \\
\text { Mines }\end{array}$ & $\begin{array}{c}\text { Circum } \\
\text { Minerals }\end{array}$ & $\begin{array}{c}\text { Allana } \\
\text { Potash }\end{array}$ \\
\hline Sylvinite Member & $1.25-9.05 \mathrm{~m}$ & $6.13 \mathrm{~m}$ & $3.51 \mathrm{~m}$ \\
\hline Upper Carnallitite Member & & $2.28 \mathrm{~m}$ & $8.81 \mathrm{~m}$ \\
\hline Bischofitite Member & $1.61-8.23 \mathrm{~m}$ & $44.10 \mathrm{~m}$ & $\mathrm{n} / \mathrm{a}$ \\
\hline Lower Carnallitite Member & & $4.93 \mathrm{~m}$ & $8.04 \mathrm{~m}$ \\
\hline Kainitite Member & $2.36-9.61 \mathrm{~m}$ & $8.78 \mathrm{~m}$ & $6.36 \mathrm{~m}$ \\
\hline $\begin{array}{l}\text { Depth of Potash } \\
\text { Mineralisation }\end{array}$ & $26-100 \mathrm{~m}$ & $200-400 \mathrm{~m}$ & $35-750 \mathrm{~m}$ \\
\hline
\end{tabular}

reaction of the Bischofitite and Carnallitite Members and has, amongst others, been described by Parsons (Parsons, 1966).

\section{Structural Geology}

According to recent geological mapping activities and exploration data, the occurrence of normal faults is reflected in seismic data as well as in the drill cores. These major northwest - southeast trending faults, dipping towards the Depression centre are related to the rift development of the Danakil Depression and favour the stepwise vertical displacement of the deposit to deeper levels from west to east (Fig. 8). As a result, the depth of the potash mineralisation is highly variable ranging from near surface in the northwest, down to $800 \mathrm{~m}$ deep in the southeast and east of the basin. In general the potash layers are sub-horizontal in the drill core material with local variations up to $30^{\circ}$ and minor folding. Although strong depth variations occur from east to west in the Danakil Depression, the average dip of the beds is estimated to be around $5-10^{\circ}$ within a single structural 'block'.

\section{Summary of Potash Resources and Potential}

Several companies are active in the area at the time of writing. Those with publicly available Mineral Resource or Reserve estimations are Allana Potash, Circum Minerals and South Boulder. The Sylvinite Member at Allana's project supports Proven and Probable Reserves of 94 million tonnes grading 28 percent $\mathrm{KCl}$ and is the focus of a Feasibilty Study for the Project. The other projects in the area are less advanced. It is possible that further potash deposits are present in the extensions of the Dallol evaporites in the southern part of the depression beyond Lake Assale, or in large Rock-salt dominated evaporite sequences in other parts of the region.

Brines from the solution mining of sylvite, kainite and carnallite can be processed to create SOP or MOP. The high temperatures of up to $55^{\circ} \mathrm{C}$ and the aridity of the area favour solar evaporation as the first processing step for total brine evaporation and crystallization of salts such as $\mathrm{NaCl}, \mathrm{KCl}$ and $\mathrm{K}_{2} \mathrm{SO}_{4}$. The ability to use solar energy is considered a significant further advantage of the projects in this area, potentially saving significant energy costs.

\section{Other African Potash Deposits and Occurrences}

\section{'Chotts' and Sabkas of North Africa}

Several large playa lakes (locally referred to as 'chotts') host ephemeral Carnallitite crusts and intercrystalline Carnallitite cements in their uppermost pan-facies sediments (Warren, 2005). The chotts are within a $\sim 1000$ kilometre-long 'belt' along the northeast extremity of the Bas Saharan Artesian Basin of the Algerian and Tunisian Sahara, and also extend into Morocco and Libya. Following sporadic flood events, evaporation leads to a Na-Mg-K-Cl-SO4 brine. Desiccation leads to crystallisation of gypsum, halite then Carnallitite as centimetre-scale layers, typically within central portions of the lowest parts of the pans. Carnallitite layers are ephemeral, dissolving with each new flood so that a significant thickness does not accumulate but $\mathrm{K}$ enriched brines are retained and enriched to a depth of 50-100 meters. The largest of the pans is Chott el Djerid in Tunisia and a historical estimate of 30 million tonnes of $\mathrm{KCl}$ was made (Northolt, 1983), in brines held in the upper $100 \mathrm{~m}$ from surface within approximately $20 \%$ of the total playa. Grades of $0.86 \mathrm{wt} \% \mathrm{KCl}$ have been reported as typical from 0-30 metre depths (Garrett, 1996). The Marada chott in Libya did produce small volumes ( 21,000 tonnes) of $\mathrm{KCl}$ from brine pits in 1939 and a reserve for a 15-square $\mathrm{km}$ area within the chott was given as 1.6 million tonnes of $\mathrm{KCl}$ (Goudarzi, 1970).

Where the aforementioned 'belt' meets the coast in Tunisia, several sabkhas exist, though they are smaller in size than the inland occurrences. The sabkha's are separated from the Mediterranean Sea by a short reach of sand and dunes. Accumulation of carnallite and kieserite has taken place by the evaporation of the seasonally fluctuating marine-fed brines. At the Sabkha el Melah, 5 million tonnes of equivalent $\mathrm{KCl}$ has been estimated to be present to a depth of 10 metres, within brine and impure Rock-salt, with grades of up to 1.22 wt.\% KCl (Garrett, 1996). Due to the low porosity of the host sediments, recovery of the brines may prove difficult.

\section{Salt Basins of Morocco}

During the break-up of Pangea, rifting led to the formation of intracratonic half-graben sags which were filled with non-marine redbed sediments and evaporites of Late Triassic to early Liassic age (Warren, 2005). Nine sub-basins have been recognised of between 50 and $200 \mathrm{~km}$ in size. In four of the basins, evaporites interbedded with basalts contain varying amounts of potash. Intervals comprising halite, carnallite, sylvite and rinneite (a secondary potash mineral: $\mathrm{K}_{3} \mathrm{Na}\left(\mathrm{FeC}_{16}\right)$ ) occur. The most detailed work has been completed on the Khemisset Basin which is comprised of interlayered clay, evaporite and volcanic (basaltic) formations. The potash is hosted by the upper part of the 'Lower Salt Formation', occurring as sylvite and carnallite within a massive banded halite unit with stringers of anhydrite and polyhalite. Drilling of approximately 130 drillholes since the 1950 s has delineated potash mineralisation at between 700 and 960 metres depth, for which an estimate of 180 million tonnes grading $15 \% \mathrm{KCl}$ has been made (Office National Des Hydrocarbures et des Mines report, 2014). The important layer has an average thickness of 4.4 metres. Within this, a Sylvinite resource of 40 million tonnes grading $20.6 \% \mathrm{KCl}$ has been quoted (Northolt, 1983). An inconsistent 
Sylvinite bed grading up to $9.5 \% \mathrm{KCl}$ has been intersected by drilling within similar evaporates of the Doukkala Basin (Garrett, 1996).

\section{Brines of the Sua Pan, Botswana}

The Sua Pan is one of the world's largest playa lakes, in northern Botswana at the eastern end of the Makgadikadi Basin. The pan is the final destination for ephemeral surface waters and shallow groundwater for a large drainage area, which over time have led to the 'accumulation' of an alkaline brine, containing significant sodium and minor potassium (USAID report, 1980). The brine is hosted within a sand aquifer of approximately 30 metres thickness and with a minimum extent of 915 square kilometres. The brines support the large soda ash and salt producing operation of Botswana Ash (Pty) Ltd. No potash is currently produced. Average analyses of brines from the pan are $4.30 \mathrm{~g} / \mathrm{K} \mathrm{KCl}$ and a contained 34 million tonnes $\mathrm{KCl}$ (equivalent) has been estimated (Gould, 1986). Historical work published by the World Bank suggests that the Sua Pan is capable of producing 163,000 tonnes per year of potash mainly as $\mathrm{KCl}$ (World Bank/SADC, 1993). Currently, Great Quest Metals Ltd. has an agreement with Botswana Ash to develop the potassium potential and suggest a 71,000 tonne per year $\mathrm{K}_{2} \mathrm{SO}_{4}$ operation is the preferred option.

\section{Acknowledgements}

John K. Warren, Department of Geology Faculty of Science, Chulalongkorn University, for his valuable contributions, review and editing.

\section{References}

Allana Potash Corp, 2014. http://www.allanapotash.com/s/ Ethiopia_Project.asp, accessed on 10 Dec 2014.

Augustithis, S. S., 1980. On the textures and treatment of the Sylvinite ore from the Danakili Depression, Salt Plain (Piano del Sale), Tigre, Ethiopia. Chemie der Erde, v. 39, p. 91-95.

Ayele, A., Stuart, G., Bastow, I., Kendall, J.-M., Keir, D., (2004). Tectonic Implication of the August 2002 Earthquake Sequence at the Western Danakhil Microplate in Northwest Afar, International Conference on The East African Rift System: Development, Evolution and Resources, 3 Pages, Addis Abeba, Ethiopia, June 2004.

Beijing-Sinoma, 2014: http://www.ecss-online.com/mining-andexploration-activities/; accessed on 04 Dec 2014.

Brinckmann, J. and Kürsten, M., 1971. Stratigraphie und Tektonik der Danakhil-Senke (NE-Äthiopien), Beih. Geol. Jb. 116, Pages 5-86, Hannover, 1971.

Brownfield, M.E. and Charpentier, R.R., 2006. Geology and total petroleum systems of the West-Central Coastal Province (7203), West Africa: U.S. Geological Survey Bulletin 2207-B, 52 p.

Carvalho, A., Alves, E., Chaves, A., 1995. Geology of the TaquariVassouras Potash Mine Sergipe State, Brazil. In Society For Mining, Metallurgy and Exploration, INC. Preprint No. 95-177.

Circum Minerals, 2014. http://circumminerals.com/project, accessed on 12 Dec 2014.

CPC, 1968. Compnanie Potasses du Congo. Service Geologique et Gisement. Campagne de sondages 1967 pour C.P.C. Sondage K51 (Nord Kouilou). Resultats des analyses chimiques des niveaux potassiques de la partie carottee de la formation salifere. 2 Mai 1968. Unpublished Company report.
Da Costa, J., Schirmer, T. and Laws, B., 2001. Lower Congo Basin, deep-water exploration province, offshore West Africa: American Association of Petroleum Geologists Memoir 74, p. 517-530.

De Ruiter, P., 1979. The Gabon and Congo Basins and Salt Deposits. Economic Geology, Vol. 74, p. 419-431.

Elemental, 2014. Company public Announcement dated 23 October 2014. Results of the Phased Implementation Update for the HighGrade Kola Sylvinite Project located in the Republic of Congo.

Eritrea-Ethiopia Boundary Commission EEBC, 2002: Decision regarding delimitation of the border between Eritrea and Ethiopia. Volume XXV, pages 83 - 195, 13 April 2002, Den Haag.

Fertecon, 2014. Potash Outlook, Quarterly Outlook for the International Potash market prepared by Fertecon analysts. Issue 2014/01. July 2014.

Garrett, D. E., 1996., Potash: Deposits, Processing, Properties and Uses: Chapman and Hall. p. 153 and 201.

Goudarzi, G. H., 1970. Geology and mineral resources of Libya - a reconnaissance: USGS Professional Paper 660, p. 104.

Gould, D., 1986. Brines of Sowa Pan and Adjacent Areas, Botswana, Mineral Deposits of Southern Africa, Geol. Soc. South Africa, pp. 2289-2299.

Hardie, L. A., 1990. The roles of rifting and hydrothermal $\mathrm{CaCl}_{2}$ brines in the origin of potash evaporites: an hypothesis: American Journal of Science, v. 290, p. 43-106.

Holwerda, U. G. and Hutchinson, R. W., 1968. Potash-bearing Evaporites in the Danakil Region, Ethiopia, Econ. Geol. 63: 2, p. 124-150, 1968.

Käding, K. C., 2008. Das Salinar der Danakil-Senke in NE-Äthiopien - Entstehung, Stoffbestand, Verbreitung, Vulkanismus und Tektonik, Kali und Steinsalz 1/2008, Pages 18-35, Kassel, 2008.

Kluge, P., 2014. Summary and Interpretation of mining information in historic Holle documentation. Unpublished Company report.

MDPA, 1976. Compte Rendu de fin de mission de M. Schlund, du 5 Aout, 1976. Dossier Congo/Tc - 31/3. Unpublished.

MDPA, 1982. Mines Des Potasse D'Alsace Company communications. Unpublished Company report.

MDPA Ingenierie, 1989. Mines Des Potasse D’Alsace, Prospection de la Potasse en Republique Populaire du Congo - Rapport de Phase 1 - Elargissement et Consolidation des Bases de Recherche - Resultats de l'Investigation Geologique, par Hirlemann G. pour SOCIETE DES POTASSES DU CONGO.

Northolt, A.J.G., 1983. Potash in developing countries. In: McKercher, R.M., ed., Potash 83-Potash technology-Mining, processing, maintenance, transportation, occupational health and safety, environment: Toronto, Canada, Pergamon Press, p. 29-40.

ONYHM, 2014. Khemissat Potash Deposit, Khemissat Province Morocco. A report by the Office National Des Hydrocarbures et des Mines.

Parsons, R.M., 1966. The Ralph M. Parsons Company, 1966: Danakil Project Ethiopia, various drawings including graphic geologic Log, Jenkins Shaft, Drawing No 1996-1-21, and Drill Hole Location Map with structural Interpretation, Drawing No 1996AA 200-3, Los Angeles.

Rauche H., Van der Klauw S., Neubert J., Franzke H. J., Wetzel H.U., 2009. Moeglichkeiten und Grenzen fernerkundlicher Methoden bei der Erkundung oberflaechennaher MineralsalzLagerstaetten, 29. Wissenschaftliche Jahrestagung der Deutschen Gesellschaft fuer Photogrammetrie, Fernerkundung and Geoinformation e. V., 24.-26. Maerz 2009, Jena.

Rauche, H., van der Klauw, S., 2013. Summary of the Feasibility Study for a Solution Mine on the Allana Potash Project, Danakil Depression, Afar State, Ethiopa. By ERCOSPLAN Ingenieurgesellschaft. Effective Date $4^{\text {th }}$ February 2013.

Rauche, H., van der Klauw, S., 2013. Resource Update for the Danakhi 
Potash Project, Danakil Depression, Afar State, Ethiopia for ALLANA Potash Corporation. 217 Pages, 30 Figures, 40 Tables, 17 Enclosures and 10 Appendices, Erfurt, Germany, 6 August 2013, effective Date 17 April 2013, accessible on www.sedar.com.

Séranne, M., Anka, Z., 2005. South Atlantic continental margins of Africa: A comparison of the tectonic vs climate interplay on the evolution of equatorial West Africa and SW Africa margins. Journal of African Earth Sciences 43 (2005) pp. 283-300.

South Boulder Mines, 2014. http://www.southbouldermines.com.au/ investor-centre/asx/; accessed on 04 Dec 2014.

Spathopoulos, F., 1996. An insight on salt tectonics in the Angola Basin, South Atlantic. In: Aslop, G.I., Blundell, D.J., Davison, I. (Eds.). Salt Tectonics, Geological Society, London, pp. 153-174.

SRK Consulting, 2012. Prefeasibility Study Volume V, Hydrological Evaluation, Sintoukola Potash Project, Republic of Congo, for Elemental Minerals.

Teisserenc, P., Villemin, J., 1989. Sedimentary basin of Gabon geology and oil systems. In: Edwards, J.D., Santogrossi, P.A.

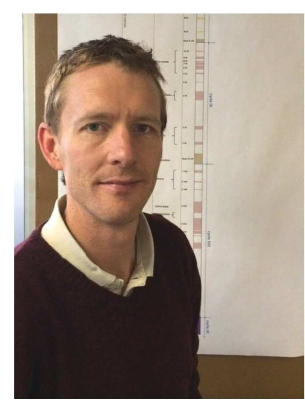

Andrew Pedly is the Chief Geologist for Elemental Minerals Limited. He has worked on the exploration and feasibility study of the Company's Sintoukola Project in the Republic of Congo since early 2012. Andrew is registered with the South African Council for Natural Scientific Professions and is a member of the Geological Society of South Africa. He has worked as a geologist in Africa since 2001 on various commodities including potash, uranium, platinum, nickel and gold. Before that he completed a BSC. in Geology at Manchester University and an MSc. in Mining Geology at the Camborne School of Mines. Andrew is married to Irene, also a geologist and they have two children, Geoffrey and Matthew. He is a well-known rock climber having established some of the hardest climbs on the crags of Waterval Boven and on the cliffs and kloofs of the Magaliesberg, in South Africa.
(Eds.). Divergent/Passive Margin Basins. American Association of Petroleum Geologists, Tulsa, pp. 177-199.

USAID, 1980. The Brines of the Sua Pan, Republic of Botswana. Submitted to the Trade and Development Program U.S. Government.

Warren, J. K., 2005. Evaporites: Sediments, Resources and Hydrocarbons. Springer, Chapter 11.

Warren, J. K., 2010. Evaporites through time: Tectonic, climatic and eustatic controls in marine and non-marine deposits: Earth-Science Reviews, v. 98, p. 217-268.

Warren, J. K., in press. Evaporites: A compendium: Berlin, Springer, ISBN 978-3-319-13512-0.

World Bank/SADC, 1993. SADC Fertilizer Supply Options Model, Washington, D. C.

Wright, T. J., Ebinger, C., Biggs, J., Ayele, A., Yirgu, G., Keir, D., Stork, A., 2006. Magma-maintained Rift Segmentation at continental Rupture in the 2005 Afar dyking Episode, Nature, v. 442, p 291-294, 20 July 2006.

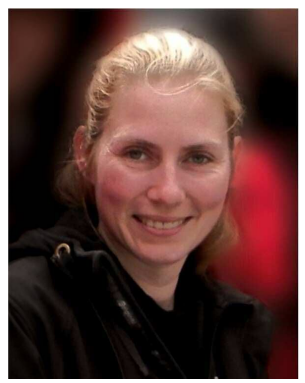

Jana Neubert is the head of deposit geology at ERCOSPLAN Ingenieurgesellschaft Geotechnik und Bergbau mbH. She has been involved in exploration and evaluation of conventional underground mining projects for potash ore and rock salt for over 13 years and in projects for the solution mining of potash and rock salt for around 10 years. Ms Neubert obtained her degree in geology in 2002 at the Friedrich-Schiller-University Jena, Germany, and subsequently completed a university trainee programme on drilling exploration in Carajás, Brazil. Ms Neubert has been working for ERCOSPLAN since 2003 and has been mostly coordinating the exploration activities, as well as the pilot plants for solution mining and solar evaporation, in the Danakhil Depression, Ethiopia. Ms Neubert is a registered European Geologist.

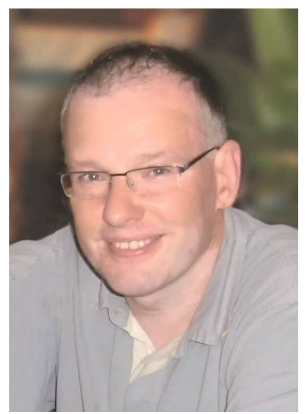

Sebastiaan van der Klauw is the head of solution mining at ERCOSPLAN Ingenieurgesellschaft Geotechnik und Bergbau mbH. He has over 20 years of experience in industrial-scale conventional and solution mining of potash ore and rock salt. Dr van der Klauw's expertise is in modelling of dissolution processes and solution mining of potash deposits. Dr van der Klauw holds a degree in geology from Utrecht University in the Netherlands, and has a PhD in natural sciences from the Ruhr-University Bochum, Germany. He has been involved in $R \& D$ activities with ERCOSPLAN since 1997 and has been working for ERCOSPLAN since 2004. Dr van der Klauw is a registered European Geologist. 